\title{
Genetic Diversity of Cowpea Genotypes Grown in the Brazilian Cerrado
}

\author{
Rita de Cássia Félix Alvarez, Aline Cordeiro Taveira, \\ Sebastião Ferreira de Lima, and Larissa Pereira Ribeiro Teodoro \\ Universidade Federal de Mato Grosso do Sul, Chapadão do Sul, Brazil
}

Job Teixeira de Oliveira

Universidade Federal do Maranhão, Chapadinha, Brazil

Adriano dos Santos

Embrapa Agroenergia, Brasília, Brazil;

Erina Vitório Rodrigues

Universidade de Brasília, Brasília, Brazil

\section{Gessi Ceccon}

Embrapa Agropecuária Oeste, Dourados, Brazil

\section{Paulo Eduardo Teodoro \\ Universidade Federal de Mato Grosso do Sul, Chapadão do Sul, Brazil}

Additional index words. plant breeding, mass of hundred grains, grain yield, Vigna unguiculata

\begin{abstract}
This study aimed to identify promising crosses to generate cowpea breeding populations for the Brazilian Cerrado region. The experiment was carried out during the two crop seasons. The experimental design used was a randomized block with four replications and 20 genotypes prostrate. The effect of genotypes was significant for all traits evaluated. The Mahalanobis distance and the Tocher's cluster were used to estimate the genetic diversity. Singh's criterion was used to quantify the contribution of each trait to genetic diversity. Mass of hundred grains and grain yield were the traits that most contributed to detect diversity among cowpea genotypes. The crosses between the G14 genotype with G2, G3, G4, G5, G6, G11, G16, and G20 are promising for the development of populations with variability and high genetic potential.
\end{abstract}

Cowpea [Vigna unguiculata (L.) Walp.] is one of the most important and strategic food sources for tropical and subtropical regions of the world. Cowpea grain contains a high proportion of protein $(19 \%$ to $35 \%)$ and carbohydrates $(63 \%)$, with low fat content (1.5\%) (Xiong et al., 2016). The crop has an important role in promoting global food security due to its nutritional characteristics and because it is considered undemanding in terms of production, making it possible to grow under low-input production systems (Horn and Shimelis, 2020). This crop has been increasingly studied in Brazil because it is grown in a wide range of environments (Santos et al., 2014, 2019), making the de-

Received for publication 13 Oct. 2020. Accepted for publication 23 Oct. 2020 .

Published online 7 December 2020.

This study was financed in part by the Coordenação de Aperfeiçoamento de Pessoal de Nível Superior, Brasil, Finance Code 001, and Universidade Federal de Mato Grosso do Sul.

P.E.T. is the corresponding author. E-mail: eduteodoro@ hotmail.com.

This is an open access article distributed under the CC BY-NC-ND license (https://creativecommons. org/licenses/by-nc-nd/4.0/). whether the genotype comprises agronomic and commercial traits that are favorable to cultivation (Guerra et al., 2017).

The objective of this study was to analyze the genetic diversity of cowpea genotypes to identify promising crossings for the Brazilian Cerrado based on agronomic traits.

\section{Materials and Methods}

The experiment was carried out in the 2010-11 and 2011-12 crop seasons at the experimental site of the Universidade Federal de Mato Grosso do Sul, Campus of Chapadão do Sul (lat. $18^{\circ} 05^{\prime} \mathrm{S}$, long. $52^{\circ} 04^{\prime} \mathrm{W}, 820 \mathrm{~m}$ ). The soil in the area was classified as Clayey Hapludox, and the climate is Aw, according to the Koppen classification. The experimental design used was a randomized block with four replications and 20 prostrate genotypes (G1 to G20) of the Embrapa Meio Norte Improvement Program. Each plot was composed of four lines with a spacing of $0.80 \mathrm{~m}$ between lines and $0.25 \mathrm{~m}$ between plants.

The traits evaluated were growth type (GT), cultivation value (CV), lodging (LOD), architecture (ARC), mass of 100 grains (MHG), and grain yield (GY). The GT, CV, LOD, and ARC were evaluated on a numerical scale described in Guerra et al. (2017). GY was obtained by harvesting the central rows of each plot and correcting for $13 \%$ humidity. MHG was obtained from a sample of the harvested grains.

Data were subjected to joint analysis of variance considering the effect of genotypes and crop season as fixed. Subsequently, the means of each genotype were used to estimate the genetic diversity among them. For this, the Mahalanobis distance and the Tocher's cluster were used. Singh's criterion was used to quantify the contribution of each trait to genetic diversity.

velopment of improved local varieties for traits of interest an essential task.

Despite being considered an undemanding, tropical crop with wide adaptation to diverse environments, cowpea presents a low average yield $\left(\approx 0.3 \mathrm{Mg} \cdot \mathrm{ha}^{-1}\right)$, even though there is evidence that its genetic potential is from 1.5 to $3.0 \mathrm{Mg} \cdot \mathrm{ha}^{-1}$ (Gbaye and Holloway, 2011) and may even exceed $6.0 \mathrm{Mg} \cdot \mathrm{ha}^{-1}$ (Ehlers and Hall, 1997). The first step for developing genotypes with greater yields is the choice of parents, which need to have genetic divergence between them and alleles favorable for better agronomic traits of commercial interest. Therefore, genetic diversity studies are necessary to assist breeders in determining the most promising hybrid combinations (Ribeiro et al., 2019; Santos et al., 2014).

In addition to grain yield, other traits of Brazilian cowpea genotypes need to be improved. The mass of 100 grains is a trait that has a direct association with yield and a direct impact on consumption because consumers prefer heavy grains. Other agronomic traits, such as plant architecture and tolerance to lodging, are also important because they affect losses during mechanized harvest. Finally, cultivation value is constituted by a scoring scale in which the breeder evaluates

\section{Results and Discussion}

The effect of genotypes $(G)$ was significant for all characters evaluated (Supplemental Table 1). Similar results were obtained in other research with cowpea in Brazil (Abreu et al., 2019; Ribeiro et al., 2019; Santos et al., 2014, 2019; Torres et al., 2016). Crop season (CS) effect was not significant only for LOD. In contrast, the $\mathrm{G} \times \mathrm{CS}$ interaction was significant only for MHG. These results demonstrate that there is no change, except for $\mathrm{MHG}$, in the ranking of the best genotypes over the two evaluated seasons.

Tocher's cluster formed eight homogeneous groups in terms of genetic diversity for the traits evaluated (Table 1). Group I allocated the largest number of genotypes (eight) and stood out for obtaining adequate averages for all traits, except for MHG. Groups II, III, IV, V, VI, and VII allocated genotypes with the lowest GY averages. Increasing GY is the main objective of cowpea breeding programs (Guerra et al., 2017; Passos et al., 2007; Ribeiro et al., 2019).

Group VIII contained the G14 genotype in isolation. This was due to the higher means of this genotype for the GY, MHG, CV, and 


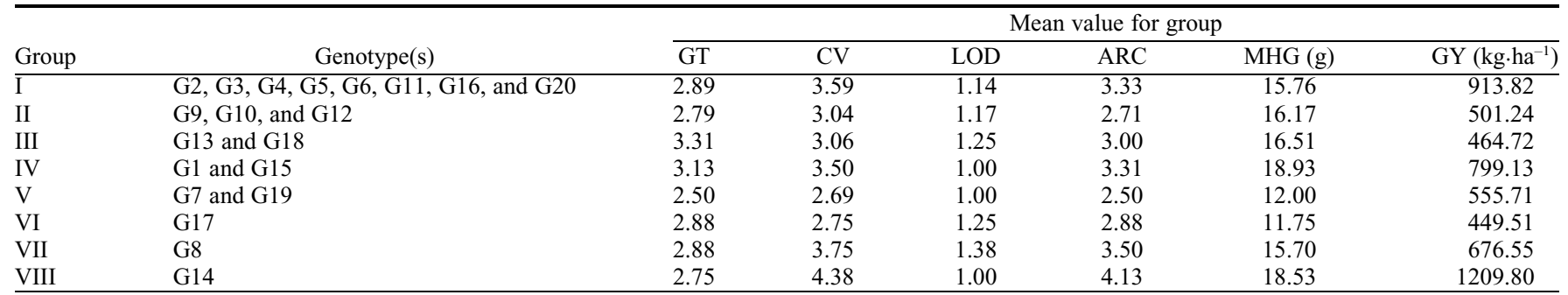

$\mathrm{GT}=$ growth type $\mathrm{CV}=$ cultivation value; $\mathrm{LOD}=$ lodging; $\mathrm{ARC}=$ architecture; $\mathrm{MHG}=$ mass of 100 grains; $\mathrm{GY}=$ grain yield.

ARC traits. Therefore, this genotype has the best productive performance, with high resistance to lodging (low averages for LOD), plants with branches, peduncles, and pods with excellent configuration (high averages for $\mathrm{ARC}$ ), in addition to desirable traits for commercial cultivation (high means for CV).

Considering that genetic variability is essential for a breeding population, the most promising crossings are between genotypes from group VIII (G14) with the ones from group I (G2, G3, G4, G5, G6, G11, G16, and G20). These crossings can generate a breeding population with high potential for selecting transgressive segregants for all traits evaluated.

By Singh's criterion, the traits GT, CV, LOD, ARC, MHG, and GY contributed $15.81 \%, 6.46 \%, 17.17 \%, 15.42 \%, 24.94 \%$, and $20.20 \%$, respectively, to the genetic diversity of 20 cowpea genotypes. MGH and GY were the traits that contributed most to detecting the diversity between cowpea genotypes, corroborating the findings reported by Santos et al. (2014). These results were expected because these traits are governed by many genes and are more sensitive to environmental effects. This can be confirmed by looking at MGH, a trait that contributed most to the diversity of genotypes and presented significant interaction with crop season.

\section{Conclusion}

Crossings between the G14 genotype with G2, G3, G4, G5, G6, G11, G16, and G20 are promising to obtain populations with variability and high genetic potential for cowpea breeding programs.

\section{Literature Cited}

Abreu, H.K.A., G. Ceccon, A.M. Correa, R. Fachinelli, E.L.M. Yamamoto, and P.E. Teodoro. 2019. Adaptability and stability of cowpea genotypes via REML/BLUP and GGE BIPLOT. Biosci. J. 35:1071-1082, doi: 10.14393/BJv35n4a2019-42125.

Ehlers, J.D. and A.E. Hall. 1997. Cowpea (Vigna unguiculata L. Walp.). Field Crops Res. 53:187204, doi: 10.1016/S0378-4290(97)00031-2.

Gbaye, O.A. and G.J. Holloway. 2011. Varietal effects of cowpea, Vigna unguiculata, on tolerance to malathion in Callosobruchus maculatus (Coleoptera: Bruchidae). J. Stored Prod. Res. 47:365-371.

Guerra, J.V.S., A.J. Carvalho, J.C. Medeiros, A.A Souza, and O.G. Brito. 2017. Agronomic performance of erect and semi-erect cowpea genotypes in the north of Minas Gerais, Brazil. Rev. Caatinga 30(3):679-686.

Horn, L.N. and H. Shimelis. 2020. Production constraints and breeding approaches for cowpea improvement for drought prone agro-ecologies in Sub-Saharan Africa. Ann. Agr. Sci. 65:83-91, doi: 10.1016/j.aoas.2020.03.002.
Passos, A.R., S.A. Silva, P.J. Cruz, M.M. Rocha, E.M.O. Cruz, M.A.C. Rocha, H.F. Bahia, and R.B. Saldanha. 2007. Genetic divergence among cowpea. Bragantia 66(4):579-586, doi: 10.1590/ S0006-87052007000400007.

Ribeiro, L.P., J.S.P.C. Evangelista, M.B. Damacena, A.M. Elizeu, I.F. Coelho, E.V. Rodrigues, P.E. Teodoro, and L.L. Bhering. 2019. Estimates of genetic divergence in cowpea by multivariate analysis in different environments. Biosci. J. 35:16811687, doi: 10.14393/BJ-v35n6a2019-42406.

Santos, A., F.E. Torres, E.V. Rodrigues, A.A. Pantaleão, L.P.R. Teodoro, L.L. Bhering, and P.E. Teodoro. 2019. Nonlinear regression and multivariate analysis used to study the phenotypic stability of cowpea genotypes. HortScience 54(10):16821685, doi: 10.21273/HORTSCI14322-19.

Santos, J.A.S., P.E. Teodoro, A.M. Corrêa, C.M.G. Soares, L.P. Ribeiro, and H.K.A. Abreu. 2014. Agronomic performance and genetic divergence among cowpea genotypes in Cerrado/ Pantanal ecotone. Bragantia 73(4):377-382, doi: 10.1590/1678-4499.0250.

Torres, F.E., P.E. Teodoro, E.V. Rodrigues, A. Santos, A.M. Corrêa, and G. Ceccon. 2016. Simultaneous selection for cowpea (Vigna unguiculata L.) genotypes with adaptability and yield stability using mixed models. Genet. Mol. Res. 15:1-11, doi: 10.4238/gmr.15028272.

Xiong, H., A. Shi, B. Mou, J. Qin, D. Motes, W. Lu, J. Ma, Y. Weng, W. Yang, and D. Wu. 2016. Genetic diversity and population structure of cowpea (Vigna unguiculata L. Walp). PLoS One 11:e0160941, doi: 0.1371/journal.pone.0160941. 
Supplemental Table 1. Mean square of the joint variance analysis for traits growth type (GT), cultivation value (CV), lodging (LOD), architecture (ARC), mass of 100 grains (MHG), and grain yield (GY) evaluated in 20 cowpea genotypes.

\begin{tabular}{|c|c|c|c|c|c|c|}
\hline Source of variation & GT & $\mathrm{CV}$ & LOD & $\mathrm{ARC}$ & MHG & GY \\
\hline$\overline{\text { Block} / C S}$ & $0.94 *$ & $1.15^{\mathrm{NS}}$ & $0.24 *$ & $2.32^{*}$ & $25.94^{\mathrm{NS}}$ & $903006.31^{*}$ \\
\hline Crop season (CS) & $71.55^{*}$ & $65.02 *$ & $0.51^{\mathrm{Ns}}$ & $49.50^{*}$ & $742.61 *$ & 2682981.00* \\
\hline $\mathrm{G} \times \mathrm{CS}$ & $0.49^{\mathrm{Ns}}$ & $1.08^{\mathrm{NS}}$ & $0.30^{*}$ & $0.73^{\mathrm{NS}}$ & $30.44 *$ & $241588.56^{\mathrm{NS}}$ \\
\hline
\end{tabular}

Ns, *Nonsignificant or significant at $5 \%$ probability by the $F$ test, respectively. 